\title{
Divine The Philosophical Foundation Policy for Tax Criminal Law Enforcement against Corporation and Natural Person in Indonesia and America
}

\author{
Timbo Mangaranap Sirait \\ \{mangaranaptimotius@gmail.com \} \\ Lecturer of the Postgraduate Masters Program in Legal Studies, Universitas 17 Agust us 1945 Jakarta, \\ Jl. Sunter Permai Raya, Jakarta 14350
}

\begin{abstract}
Tax has been an important element necessary to support the wheel of a State. Initially, it was only a grant or tribute, the first is termed grant since tax is paid voluntarily while the latter is termed tribute since it has forced value and is criminally punishable for either Legal or Natural Person against those violating same. Although the role of tax is very important and corporation is declared as subject of criminal law, however there are numerous tax criminal cases in Indonesia or in America which has created the need to study the historical and philosophical foundation to see why the tendency in the enforcement is to punish particular subject of law. This research was conducted by juridical normative and legal comparison method, that tax crime is closely related to "conditio sie qua non" theory and adagio "Universitas delinguere nonpotest" (legal entity is not criminally prosecutable), which is a philosophical the Tax Crime Law Enforcement therefore in the case of Corporate as actors, there is a tendency that criminal liability will be most likely to the Natural Persons
\end{abstract}

Keywords: Philosophy, Law enforcement, Corporate Crime, Tax

\section{Introduction}

Along thehistories of the nations from the ancient Egypt, Greek and Rome through the modern era in Indonesia and United States nowadays, Tax has been an important element to support the government of a country, this is aligned with the opinion of Ross [2004] stating that "taxation was central to state-building. In its early stage, they were gift or tribute, it was called gift because taxwas voluntary while tribute was paid with prescribed value in force and which imposed penalty or imprisonment for those not complying with the rules.

The historical foundation inspired the definition of Tax as obligatory (Das sollen) in the positive law or literatures in numerous countries being the obligatory contribution to the country payable by Natural Persons or Legal Person (Corporation) having the force of law, without direct reward and used for the purposes of the country in the pursuit of the people prosperity. On the other hand, Hector De Leon [1993] defined Tax as a proportional contribution by the people from their as sets prescribed by law to support the government in fulfilling the need of the community, while the definition of Taxaccording to the literatures of Blacks Law Dictionary [Garner 1999] stated that Tax is "A monetary charged imposed by the government on persons, entities, or property, to yield public revenue. 
According to the said definition of tax, it is explicit that there has been broader tax subjects, which in the ancient times, governed only Nutural Person (Natuurlijke Persoon) which has currently covered Legal Person (Recht persoon) as a Subject Taxpayer paying the contribution to thestate revenue to promote the government and expenditures for the state development in the pursuit of the people welfare.

Taxation plays a very importantrole for the people's welfare in each country, however in the empirical domain, (Das sein) there are cases of tax crime in the course of its enforcement which turned out to be phenomenal involving the legal person, as stated in the Annual Criminal Investigation Report at the Internal Revenue Services (IRS 2018) United States in 2018 where IRS United States was successful in combating the corporate tax crime, while in Indonesia according to the Directorate General of Tax [www.pajak.go.id, accessed November 24, 2019] “... the most prominent taxcrime was PT. Asian Agri Group with total state loss of 1,25 trillion rupiahs, Tax Invoice Discrepancy (Not Bas ed on actual transaction) from Amie to the seven companies over IDR 123 billion (Kompas.com, accessed November 24, 2019). Although the taxcriminals in the United States and Indonesia are legal person (corporation), however, enforcement tends to impose criminal liability and charge on the Natural Person where the proceeds from the tax crime are most enjoyed by the Corporation.

In the substantive view of idealtax law (das sollen) for the legal norms in the Indonesian U.S. leg is lations, the idealobject demand of justice is achieved, where this, at least, is shown by the balance in the charging of the person, whether natural or legal pers on (corporation), who commit the tax crime, however, in the empirical domain, viewed from the enforcement model and criminal penalty which focuses on the natural person, in-depth contemplation is neces sary to reflect the his torical and philosophical foundation so as to identify the reasons of the enforcement. The purpose is, at least, to respond to the public who lack of knowledge in tax law and to prevent from new sense of injustice among the society, it is known in the United States and Indonesia that in each corporate tax crime, the crime has always been committed by the legal person, but the liability is charged on the Natural Person.

The legal issues raised in this paper are How is the history of tax law enforcement policies against corporate tax offenders?, and What is the philosophical foundation of the Criminal Prosecution Policy of Corporation committing Tax Crime in Indonesia and United States ?

\section{Discussion}

\subsection{The birth of Corporation (1243) as the subject of tax law and the His torical Policy for the Law Enforcement}

According to T. Mangaranap Sirait [2019] the history of tax collection and taxable subjects covered and the enforcement of punishment has evolutionary changed, dynamically progressing fromtime to time along with the social development of the communities and the increased role and function of tax in a country. In the ancient Egypt, theorder of law of nature still dominated the field of law and written law was in stagnancy. In the said epoch, the tax law subject was solely Natural Person, meanwhile, legal person was not acknowledged as the subject of tax law. In the era of King of Pharaoh, the tax obligatorily collected in form of voluntary gift or tax was made by the king as an important element to support and finance the 
operations of the kingdom and the construction cost of pyramid, and it proved that tax supporting the ancientEgyptkingdomremains in existence and even more well-known for its superpower despite the prolonged famine faced by the country.

Later in the Greek era, at the birth of philosophers such as Socrates, Plato, and Aris toteles, there was invented more humane and democratic tax collection policy, however the policy did not straightly develop and accepted as the model for tax enforcement in the Roman era. After the Romans conquered Greek, the Greek culture was assimilated into the roman culture irres pective of its position as a colonized country, Greek arts, literatures and philosophy began to infiltrate the Roman society with increasingly dominant influence (de Cruz 2014). However later in the era of Roman kingdom, the policy for tax law enforcement was more repressive. Small kingdoms were even conquered, taking oath of allegiance to the Rome and obliged to pay cross border tax to the King of Rome as a symbol of fellowship and submission and to place sense of security to the kingdomby the Roman ruler.

Although written tax criminal law (lex scripta) was not fully complete in the Roman era, the tax collector (Publican) had the authority for tax law enforcement under the rule of "criminal extra ordinaria" expanding their coverage of crimes not defined in the law, accordingly, under the rule of "criminal extra ordinaria" Tax collector was authorized to render penalty or physical punishment like forced labor or caning against the tax violators. His torically, since the ancient time, evasion has been considered tax crime "Criminal Extra Ordinaria" that may be subjected to severe punishment.

The origin of the new taxable subjects started in the era of Paus Innocent IV (1243) who was also a legal expert. "According to Dwidja Priyatno the term corporation was first introduced in European region marked by the formation of Church Board in 1243 by Paus Innocent IV and the Church as a legalperson with assets separate from those owned by the members" [Gunakaya 2014]. Further, according to Muladi and Dwidja Priyatno [2010], in the mid century, which mas marked by the decline of the Roman power, and weak trade, then it was impossible for people to engage in business/trade without support by military and social order. During that era in Europe, the growth of corporation was marked by the Church Board influenced by Roman Law. The church owned as sets separate from those of the members and distinguished fro the subject of human law. Church, as the early corporation was first introduced by Paus Innocent IV. In line with the development of social condition in 1243, Paus Innocent IV (1243) is sued an announcement that legal person was not subjected to criminal prosecution with the adage known as "Universitas Delinguere Non Potest. This is the adage which made legal person more elastic in the business compared with Natural Person, which has to this date been influential on the enforcement of criminal liability against legal person, where although the taxcriminal is a legal pers on, thepunishment tend to be imposed on Natural Person, the administrators or agents. According to the constituents leg al person is a bodiless and invisible entity, soevilthings charged with liability rests with the Natural Person controlling the corporation. 


\subsection{Tendency to Penalize Natural Person in Corporate Tax Law Enforce ment in America}

After the American continent was discovered by Columbus (1492), residents of 13 colonies in America were required to pay levies to the British colonial government through legislation policies The Stamp Act (1765) and The Townsend Act (1767) which required each resident of the colonies to pay taxes on purchase of various things, and this then became one of the triggers of the American Revolution. With the opposition to the tax policy, it illustrates that community participation and representation play an important role in realizing effective tax law enforcement. During theindependence revolution in America, independence support groups protested the taxpolicy that required 13 colonies to pay taxes to Britain, even though they had no representation in parliament. Because of this, according to Rochmad Soemitro, an argument applies in America that "Taxation without representation is Robbery." [Soemitro 1977].

The importance of representation in Parliament for tax validity in America was then explicitly regulated in Section 8 of the American Constitution that read "The Congress shall have power to lay and collect taxes, duties, imposts and excises, to pay the debts and provide for the common Defence and general Welfare of the United States", and was then confirmed by the $16^{\text {th }}$ Amendment to the American Constitution that read "The Congress shall have power to lay and collect taxes on incomes, from whatever source derived, without apportionment among the several States, and without regard to anycensus or enumeration." Through this Constitution, Internal Revenue Code and Internal Revenue Services were then born as tax authorities, including enforcing tax criminal law in America.

Subsequently, 133 years after declaring the independence (4 July 1776) America admitted Corporations as criminal law subjects in 1909, i.e. through a court (the Supreme Courts) decision in the case of New York Cental and Hudson Riwer R.R.v. United States, and through that decision a Corporation (a Legal Person) and a Natural Person already had a parallel position in the criminal law. It was continued with the matters in the tax law, so although the Sanction of penalty was applied differently, in the American Tax Law a Corporation that is a tax criminal perpetrator is acknowled ged in parallel to an NaturalPerson, which is deemed as a crime that is in violation of the Internal Revenue Code of America, in the form of falsification of corporate and Natural Person tax restitution. A tax crime on the Internal Revenue Code is an exclusive investigation juris diction of the American Crime Investigation (CI).

The parallelis mbetween a Corporation and an Natural Persons in the American Taxation Laws and Regulations is seen as the U.S. Code Title 26-Internal Revenue Code, U.S. Code $\S$ 7201.Attempt To Evade Or Defeat Tax) which reads as follows:

Any person who willfully attempts in any manner to evade or defeat any tax imposed by this title or the payment thereof shall, in addition to other penalties provided by law, be guilty of a felony and, upon conviction thereof, shall be fined not more than $\$ 100,000$ (\$500,000 in the case of a corporation), or imprisoned not more than 5 years, or both, together with the costs of prosecution. 
According to the Department of the Treasury Internal Revenue Service of America, the Corporate Tax Fraud Program concentrates on violations committed by public or private companies and senior corporate executives. Some corporate tax offenses include faking, is suing, or des troying company accounting records to falsify tax returns, financial reports, or reports to regulatory agencies or investors. This also includes executives giving their rights to unauthorized compensation, using unapproved payments, bonuses, corporate funds, or fake loans to pay for personal expenses [IRS 2018].

According to the report of the Internal Revenue Services (IRS) of America in 2018, there were 74 corporate law subjects (Legal Person) as criminal perpetrators who were investigated and 35 corporations have been sentenced, but according to the report, most of them were NaturalPersons (Natuurlijke Persoon), i.e. the management executives of the corporation, whereas according to the provisions of the U.S. Code Title 26-Internal Revenue Code U.S. Code $\S 7201$ Attempt To Evade Or Defeat Tax there should be a sanction of penalty to be applied to the corporation which should be five (5) times more severe.

The tendency to punish the legal subjects of Natural Persons more than Corporations (Legal Person) in the IRS: Criminal Investigation Annual Report 2018, can among others be seen in the case of Street Corporation Crime of Alcapone where Alcapone was sentenced, Chicago Scrap Iron Refining Company, and Its President Sentenced for Criminal Tax Violations, Laurence C. Baron was sentenced to 1 year in pris on, 1 year of supervised release, and ordered to pay $\$ 1,333,084$ in restitution. On the same date, a judgement ordered that funds, seized from Acme Refining Company would be applied to pay an outstanding restitution judgment of $\$ 4,545,243$ and a fine of $\$ 500,000$, and Ebong Tilong, the owner of a Houston home health agency, was sentenced to 80 years in prison for his role in a $\$ 13$ million Medicare fraud scheme and for filing false tax returns. Tilong pleaded guilty to cons piracy to commit healthcare fraud, healthcare fraud, conspiracy to pay and receive healthcare kickbacks, payment and receipt of healthcare kickbacks, conspiracy to launder monetary instruments, and filing fraudulent tax returns. Shiv D. Kumar, the former president, and sole shareholder of A-Paratransit Inc. (API), was sentenced to almost 1 1/2 years in prison and 1 year of supervised release for filing a false corporate tax return. Kumar pleaded guilty on April 20, 2018, to underreporting income on API's 2010 corporate tax return. Randy K. Small the owner of RSB Leasing was sentenced to 3 years in prison and ordered to pay $\$ 1,694,725$ in restitution. On June 20,2017, Small pleaded guilty to failure to pay $\$ 1.7$ million to the IRS in payroll taxes [IRS 2018].

\subsection{Tendency to Penalize Natural Person Legal Subjects in Enforcement of Corporate Tax Law in Indonesia}

The history also records, in Indonesia itself the application of the Tax system has existed since the days of the "Kings of Java", then developed in the $7^{\text {th }}$ century during the glory of the power of the Srivijaya kingdom, the kingdomimposed a taxon every ship passing through the Strait of Malacca, the customs duty of ships that stopped at the port, including imposing taxation on the merchandise carried by Private Merchants (at that time business activities are not in the form of a corporation) that trades individually. Then it continued in the Majapahit kingdomunder the leadership of the Supreme Patih (Great Minister) Gajahmada could reach the peak of its glory in the mid- $14^{\text {th }}$ century, one of which was supported by a good taxation system so that it successfully mastered and was respected in the Asian peninsula. 
In the historical record of Indonesia (Dutch East Indies) is also found, a world-scale corporation has existed and been known since 1602, with the inclusion of the Vereenigde Oostindische Compagnie (VOC), the first multinational corporation to come to trade and monopolize the spice commodity, but due to the influence of Pope Innocent IV's proclamation that said "Delinguere Non Potest University" which influenced the Dutch criminal law, made the VOC corporation not prisoned despite many crimes in its efforts to increase tribute or taxes from the people while in power in Indonesia. So since Verenigde Oost Indiche Compagnie (VOC) there has been a tribute system. Then the VOC went bankrupt and was replaced by Daendels (1808-1881) declaring an effort to stop all deposits of agricultural products and replace them with Taxes, Tribute, Excise and recognition fees. Deposits of agricultural products such as rice, sugar, beans, cotton, candles, oil, indigo, pepper, fruits are abolished, and stipulated Taxin the form of Money as a legal Tax payment instrument at that time.

After Indonesia gained its independence from the Netherlands, Tax has a constitutional bas is through Article 23A of the Third Amendment to the 1945 Constitution which states that "Taxes and other levies that are coercive for the needs of the state are regulated by law", this is the constitutional bas is for the birth of various leg is lative regulations. tax laws in Indonesia. Therefore "... Taxes include public law and this is part of the legal order that regulates the legal relationship between the authorities and the people / citizens regarding rights and obligations [Bohari 2010], as well as being the legal bas is for the Civil Servant Investigator (PPNS) Director General of Taxes having the authority as a Special Investigator of tax crime in Indonesia.

Although it frequently updates the taxnorms, the Indonesian Directorate General of Taxes has also regulated a rigid taxation system. Acts deemed as Tax Crimes that can be done by Corporations or Natural Pers ons negligently or intentionally are regulated in various taxation legislation including Law Number 16 of 2009 concerning General Provisions and Procedures for Taxation, Law Number 36 of 2008 concerning Income Tax, Law Number 42 of 2009 concerning Value Added Tax and Sales Tax on Luxury Goods, Law Number 12 of 1994 concerning Land and Building Tax, and Law Number 13 of 1985 concerning Stamp Duty.

After a long time the corporation has not been touched by the criminal law because it is only considered as a subject of civil law, but given the increasingly unsettling behavior of corporations in the community, the Indonesian Lawmakers began to consider it as a criminal law subject, so that since 1951 it was made corporate norms as subjects of criminal law in the Law on the hoarding of goods, and further expanded in Article 15 paragraph (1) of Law Number 7 Drt. 1955 Concerning Economic Crimes, and up to now continues to various other laws and Procedural Laws of the Supreme Court Regulation No. 13 of 2016 concerning Procedures for Handling Criminal Cases by Corporations.

By making corporations the subjects of criminal law since 1951 in Indonesia, the tax corporate criminal context has also been regulated as the perpetrators of tax crimes, as stipulated in a balanced manner including Article 39A of Law Number 16 Year 2009 concerning General Provisions and Tax Procedures that reads that "Any Person who intentionally Is sues and/or uses taxinvoices, proof of taxcollection, proof of tax withholding, and/or proof of taxpayments that are not based on actual transactions or Is sues a tax invoice but not yet confirmed as a Taxable Enterpreneur shall be sentenced and fined". 
Almost similar to America, des pite the vast definition of the corporation in the Indonesian Tax Regulations, but when tax crimes occur with corporate legal subjects, the law enforcement remains paradoxical because most of those who are held accountable for corporatetaxcrime are legal subjects of the Natural Persons, either as a Director, Executive Manager, Tax Consultant, Financial Manager or corporate employees who are related to the corporate crime. According to the record, the Court Decision which firmly convicted corporations of taxoffenses was found only in the " PT. Asian Agri Group" corporation tax case which caused the state to suffer a los s of IDR 1.25 trillion. The case was adjudicated by the Supreme Court Judge at the cassation level of the Supreme Court of criminal fines of more than IDR 2.5 trillion, but still punis hes the legal subject of the Natural Pers on with a decision of 2 years in prison with a trial period of 1 year.

\subsection{Philosophical Basis for Enforcement of Tax Criminal Law on Corporations of Criminal Perpetrators in Indonesia and America}

The word "Philos ophy" (philosophy, filosofie) originates from two words in the Greek, namely: "philia" (love) and "shophia" (wisdom). Initially it means (refers to) almost all investigations that demand intellectual efforts (common sense) [Patrick 2008] which is common among law students in philosophical activities, for example to reflect the gap between the ideal norms of tax law (das sollen) and the tax law enforcement in reality (das sein) against the corporations that are the tax criminal perpetrators in both Indonesia and America.

Because as the world law students agree that where there are people (communities), both corporations (LegalPers ons) and Natural Pers ons, there will be a law, and as societies develop in a country, law and development will also grow according to the development of that society, and the role of tax revenue as a pillar of development for the welfare of the community is increasingly needed, butparallel with the sociological development Tax crimes also increase, causing new gaps in enforcement, and inequality in enforcement needs to be explored philosophically when it is so.

The gap in law enforcement that needs to be explained, concerns the philos ophical bas is why in the case of taxcrime with corporate perpetrators, in fact it is those who are often held liable for criminal liability are the legal subjects of the Natural Persons. Mardjono Reksodiputro [2004] indeed said where "... in the beginning it was held in Indonesia that the burden of duties (zorgplicht) to manage a "unity of people" or corporation must be on its management, the corporation is not the subject to criminal law. This opinion then developed into an acknowled gment that the corporation can act as a perpetrator (dader), but that criminal liability (prosecution and punishment) remains with its management. The penalization can only be removed if the administrator can prove that he is not involved.

If the gap is to be answered but only in terms of the Juridical or Theoretical level, then it will indeed face a deadlock and it is rather difficult to explain, because in the tax law norms it is clearly said that Everyone, both Natural Pers ons and Corporate Perpetrators of tax crime must be as ked criminal liability. Therefore, the lovers of wisdom through deep reflection need 
to find philosophical reasons for the tendency to convict Natural Persons rather than Corporations in corporate tax crime.

Times have changed, Corporations that were initially born as a result of philosophical activities (pondering) Pope Innocent IV in 1243, in which there must be a new Legal Subject to fill the empty space in economic activities, and social activities in the Civil field, but now the responsibility has been expanded from being only Civil in nature, to being expressly considered able to possess evil things (Mens Rea) in Indonesia since 1951 and in America since 1909 being subject to criminal law. In the field of corporate economics it is more powerful than Private Natural Persons in all sectors of life, and is given more ease in doing businessand access to Banking compared to the subject of Natural Pers ons. Corporations are considered to be a very large source of taxrevenue compared to Natural Pers ons. This point of view has made in tax criminal cases that are always given a deterrenteffect, that is the Natural Pers on, that is the Management of the corporation, while the corporation itself is almost never convicted, even though it also enjoys the benefits of the crime.

Judging from the course of the tax history above, the pattern of law enforcement is more criminal to the Natural Pers ons even though the perpetrators of the taxcrime are Corporations arising from the philos ophical thinking that has been around for a long time, adherents of this view assume corporate taxcrime is essentially considered the effect of " conditio sine qua non" and sociologically occurin various countries such as in the United States and in Indonesia. Eddy O.S. Hiariej [2016] said that the theory of conditio sine qua non is also called an absolute theory which states that a dis aster is every condition that cannot be eliminated for the consequences. This theory was put forward by von Buri, Chairman of the German Supreme Court. According to Von Buri, the terms (bedingung) are identical to the causes and therefore each condition has the same value (equivalent). So, because there are so many causes that can trigger the emergence of various forms of tax crime, the arrangements and enforcement also vary by country.

Other conditions that are the causes resulting in a tax crime, arising from the paradoxes in the substance of the legislation, for example in Indonesia there are norms that implicitly prevent the validity of the Law Fiction Theory in legislation tax invitations which say that "everyone is considered to know the laws and regulations after being announced in the State Gazette". The paradox is a logical consequence of Article 49 paragraph (3) letter a Government Regulation Number 74 of 2011 concerning Procedures for the Implementation of Rights and Fulfillment of Tax Obligations regulating that "A power of attorney not a tax consultant is deemed to have mastered the provisions of tax legislation if he can attach a photocopy of a "Brevetcertificate" or "formaleducation degrees in taxation" issued by public or private tertiaryinstitutions with an A accredited status, at least Diploma III level. This Article has at least implicitly derogated the Legal Fiction Theory because there is an additional requirement that a pers on is considered to know tax regulations and is no longer merely because the tax regulations have been announced in the State Gazette.

The problem that arises is when the legal attorney in the proceedings (Corporate Management, Lawyer) acts on behalf of the Corporation but is not a taxconsultant, however is a legal expert and/or has qualifications as a legalexpert but does not have a Brevet Certificate or a formal education certificate in taxation, then in the tax criminal case the absence of the Brevet Certificate and Tax Diploma is categorized as a Person who does not master the 
provisions of taxlegis lation, only because the main conditions of the Brevet Certificate and Tax Diploma are not fulfilled.

With the absolute requirement that there must be a Brevet Certificate and a Tax Diploma so that they are considered to know taxregulations, the Corporation as a legal subject can also be qualified as a pers on who does not know the taxlaw as well, and therefore it is not possible for a Corporation that does not understand the law to be deemed to have committed an act criminal for something he does not understand the prohibitions that may not be carried out in the Tax Law. This is one of the cau ses of corporate crime, but the corporation is not convicted. This condition has become a reas on for forgiving Corporations from being convicted, that is, corporations are considered to have committed criminal acts because they do not understand tax law, because it is impos sible for people who do not understand the law to be convicted. "... Ignorantia eorum quae scire non excusat tenetur (ignorance of something that should be known) is a condition to be forgiven [Ranuhandoko 2013].

Moreover, if contemplated more deeply rooted, there is a tendency of tax penalization that tends topenalize a NaturalPerson in a Corporate taxcrime, which is the impact of the theory of "conditio sine qua non", then the matter also occurs as a result of the thought that corporations donothave a natural body so it is not possible to have evil things (mens rea) with the adage "Universitas Delinguere Non Potest" or "Societas Delinguere Non Potest", and the implications of the adage make the taxcriminal law put forward the principle of "Ultimum Remedium" a legal term that means that the application of criminal law is only the ultimate weapon in the case that the application of other laws is ineffective. Through this principle of "Ultimum Remedium", corporations in the tax law are given the opportunity to admit their mistakes by making corrections to their mistakes and then not be convicted.

The conditions mentioned above are the reasons why in Indonesia and America there is a tendency for taxcriminal law to be more liable to convict Natural Pers ons than Corporations (Legal Persons) as the legal subjects. Natural Person even get a double sentence, in addition to being sentenced to prison, sometimes they are also given financial penalties. For the legal subject of Natural Persons, the applicable terminology is "Ignorantia juris quod quisque tenetur scire neminem excusat" which means ignorance of the law when it should be known, will not be forgiven [Ranuhandoko 2013]. Meanwhile, corporations, even if convicted, are only in the form of fines, because theirignorance of the leg al facts is considered as a forg iving reason for not being accused (Ignorantia facti excusat).

The paradox in the tax criminal law mentioned above is an irony of the law, because on one side there is an equal arrangement before the law for 2 (two) tax law subjects, but on the other hand in its enforcement it still tends to be biased in the legal subjects of Natural Persons compared to corporations (Legal Persons). If it reflects on the legal terminology that says "minima poena corporalis est major qualibat pecuniaria" (the smallest corporal punishment is greater than a fine), which means that whatever the sanctions imposed on corporations, then it is not comparable to prison sanctions received by the Natural Persons.

Through the explanations above, it is now clear that the imbalanced Pattern of law enforcement and the imposition of severes anctions on the Legal Subjects of Natural Persons and Corporations was born fromthe perspective of a long-standing legal philosophy, which argues that it is not likely to punish corporations without natural bodies and invisible to the 
adage of "Universitas Delinguere Non Potest" or "Societas Delinguere Non Potest", and because of the adage, the person responsible for the actions of the corporation shall be its Natural Persons who take care of and move the corporation. Regarding the philosophy of human mind, Oliver Wendell Holmes, a federal judge in the United States stated that "an act is a willed muscular contraction, nothing more" or Johh Austin who is different from Holmes argues that "An act is voluntary movement of my body or a movement which follows a volition "[Atmasasmita 2018], and because the legal subject is the Natural Person who drives the corporation, it is the Person who takes care of the corporation that shall be responsible and convicted.

\section{Conclusion}

The conclusion of this article are Firstly, his torically although a corporation has been long known as a civil law subject in Indonesia and America, but in the criminal policy on corporations as criminal perpetrators was justregulated by the Law maker in 1951, and now it is increasingly developing, including it being regulated in the Indonesian Tax Laws and Regulations, whereas in America the regulations on corporations as the criminal law subjects were initially is sued through the juris prudence of the Supreme Court Decision in 1909 and then increasingly developing, including the Internal Revenue Code of America. However, although according to historical records in Indonesia and America, it is clear that the regulations and policies of laws on penalization against corporations as tax criminal perpetrators, in practice the enforcement tends to account for the penalize the Natural Persons who manage the Corporations. Secondly, the Law Enforcement philosopy against Corporations as the TaxCriminal Perpetrators in Indonesia and the United States of America lies on the old view that a tax crime is the result of the "conditio sine qua non" and also the old thought which brings about the adage "Universitas Delinguere Non Potest" which basically states that the corporation has no natural body, so it is impos sible to have bad faith as a reas on for penalization, so it is the Natural Persons who manage the corporation shall remain to be held responsible for penalization against corporate perpetrators of tax crime, i.e. the legal subjects of Natural Persons in the form of the corporate Management that has a natural body and also evil things to commit and drive the tax crime.

\section{Reference}

[1] A. D. Putera, "Fake Tax Invoice Case, Amie Hamid subject to Additional Verdict from South Jakarta District Court". Wired, 11 January 2018, [Online\} available at: https://ekonomi.kompas.com /read/2018/01/11/113000326/kasus-faktur-pajak-palsu-amie-hamid-kena-vonis-tambahan-dari-pn-jaksel , (accessed 24 November 2019).

[2] B.A. Garner, Blacks Law Dictionary. Minn: Seven Edition, ST. Paul, 1999.

[3] Department of the Treasury Internal Revenue Service of USA, IRS:Criminal Investigation Annual Report 2018, Publication 3583 (Rev. 11-2018) Catalog Number 29201R, 2018.

[4] Directorate General of Taxation of Indonesia, Settlement of Tax Crimes Cases, Wired [Online] available at: https://www.pajak.go.id/id/artikel/penyelesaian-kasus-tindak-pidana-di-bidang-perpajakan, (accessed 24 November 2019).

[5] E.O.S. Hiariej, Criminal Law Principles, Revised Edition. Yogyakarta: Cahaya Atma Pustaka, 2016.

[6] G.T.W. Patrick (et.all), B.A. Sidharta (ed), What is philosophy and philosophy of science. Bandung: Pustaka Sutra, 2008.

[7] H. Bohari, Introduction to Tax Law. Jakarta: Rajagrafindo Persada, 2010. 
[8] H.S. Leon, The Fundamental of Taxation. Manila, Philippines: Rex Book Store, 856 Nicanor Reyes, C.M. Recto Avenue, 11th edition, 1993.

[9] I.P.M. Ranuhandoko, Legal terminology. Jakarta: Sinar Grafika, 2013.

[10] M. Reksodiputro, "Corporate Crime is an Old Phenomenon in a New Form", Indonesian Jurnal of International Law, Vol. I no. 4 July, 2004.

[11] M.L. Ross, "Does Taxation Lead to Representation?. Cambridge: Cambridge University Press, 2004.

[12] Muladi and D. Priyatno, Corporate Criminal Liability. Jakarta: Prenada Media Group, 2010.

[13] P. de Cruz, and N. Yusman (translator), Comparison of Legal Systems, Common Law, Civil Law and Socialist Law. Bandung: Nusa Media, 2014.

[14] R. Atmasasmita, Reconstruction of Criminal Principles Withour Culpability,Geen StrafZonder Schuld. Jakarta: Gramedia Pustaka Utama, 2018.

[15] R. Soemitro, The Basic Tax Law and Income Tax 1944. Bandung: Eresco,1977.

[16] T. M. Sirait, Indonesian Tax Criminal Law (Material and Formal). Yogyakarta: Depublish, 2019.

[17] W. Gunakaya, Introduction to Legal Studies. Bandung: Pustaka Harapan Baru, 2014. 